\title{
501 Years of Spring Precipitation History for the Semi-Arid Northern Iran Derived from Tree-Ring $\delta^{18} \mathrm{O}$ Data
}

\author{
Zeynab Foroozan ${ }^{1, *}$, Jussi Grießinger ${ }^{1} \mathbb{C}$, Kambiz Pourtahmasi $\left.{ }^{2} \mathbb{(}\right)$ and Achim Bräuning ${ }^{1}$ \\ 1 Institute of Geography, Friedrich-Alexander-University Erlangen-Nürnberg, 91054 Erlangen, Germany; \\ jussi.griessinger@fau.de (J.G.); achim.braeuning@fau.de (A.B.) \\ 2 Department of Wood and Paper Science \& Technology, Faculty of Natural Resources, University of Tehran, \\ 31587-77871 Karaj, Iran; pourtahmasi@ut.ac.ir \\ * Correspondence: zeynab.foroozan@fau.de
}

Received: 24 June 2020; Accepted: 20 August 2020; Published: 22 August 2020

\begin{abstract}
In semi-arid regions of the world, knowledge about the long-term hydroclimate variability is essential to analyze and evaluate the impact of current climate change on ecosystems. We present the first tree-ring $\delta^{18} \mathrm{O}$ based hydroclimatic reconstruction for northern semi-arid Iran spanning the period 1515-2015. A highly significant correlation between tree-ring $\delta^{18} \mathrm{O}$ variations of juniper trees and spring (April-June) precipitation reveals a major influence of spring water availability during the early growing season. The driest period of the past 501 years occurred in the 16th century while the 18th century was the wettest, during which the overall highest frequency of wet year events occurred. A gradual decline in spring precipitation is evident from the beginning of the 19th century, pointing to even drier climate conditions. The analysis of dry/wet events indicates that the frequency of years with relatively dry spring increased over the last three centuries, while the number of wet events decreased. Our findings are in accordance with historical Persian disaster records (e.g., the severe droughts of 1870-1872, 1917-1919; severe flooding of 1867, the 1930s, and 1950). Correlation analyses between the reconstruction and different atmospheric circulation indices revealed no significant influence of large-scale drivers on spring precipitation in northern Iran.
\end{abstract}

Keywords: $\delta^{18} \mathrm{O}$ chronology; climate reconstruction; Juniperus polycarpos; climate extremes; stable isotope dendroclimatology; paleohydroclimatic proxy

\section{Introduction}

Iran is located in western Asia, in one of the world's most water-scarce and dry regions of the Middle East [1,2]. Due to its geographic location between the arid to the semi-arid mid-latitude belt and the subtropical zone, and complex topography, Iran is highly sensitive to climate change [3]. Nearly $85 \%$ of the Iranian land area is characterized by arid or semi-arid conditions, underlining the vulnerability of the region to climate change, especially to changes in hydroclimate [4-6].

Adaptation to climate change requires concerted efforts in different sectors to seek accurate baseline information about the range and magnitude of past and projected changes in climate as well as region-specific vulnerability analyses of climate change. A study examining the output of 18 global climate models presumed that the Eastern Mediterranean region including northeastern Iran will encounter a substantial decrease around $15 \%$ of the current annual precipitation by the end of the 21 st century [7]. In addition, the timing of maximum precipitation in northern Iran is postulated to shift from April to November, which will very likely affect the regional water supply during the growing season [7]. 
Climate change is expected to have even more sound and financial impacts on developing countries with manifold effects on water resources, and will affect the type, frequency, and intensity of extreme weather events, such as floods, droughts, or heavy precipitation events [8,9]. Despite the great impact of climate change for this region, its effects on meteorological variables have not sufficiently received inquiries, both locally and regionally. Recently, the interest in Iran for analyzing trends in climate has increased. The majority of these studies concluded considerable and adverse changes in climate and hydrological parameters [10] towards generally warmer and drier climate conditions in Iran [11,12], which will consequently lead to an extension of semi-arid areas. In particular, such expansion already occurs in the dryer regions of Iran [13]. Tabari and Aghajanloo [14] postulated an increase in aridity at 10 stations located in sensitive agricultural regions in Iran, which was caused by the concurrent occurrence of a negative precipitation trend and a positive evapotranspiration trend. Tabari and Willems [6] pointed to a slight increase in the number of dry days and longer drought periods (up to $90 \%$ ) for almost the entire Middle East and showed that in the future prolonged droughts will further aggravate the already high level of regional water stress.

However, these studies rely on datasets from meteorological stations only providing climate records since the 1950s. The shortage of instrumental climate data series, which often show a substantial portion of missing data, poses a challenge to derive robust trends of recent climate change. Since the spatial density of meteorological stations is very scarce over large parts of Iran, it is difficult to draw sound conclusions about changes in moisture-bringing atmospheric circulation systems [11].

In this context, natural climate archives offer important assistance. Fingerprints of past climate variations recorded in annually resolved tree rings offer great opportunities for high-resolution paleoclimate reconstructions $[15,16]$. The analysis of stable oxygen isotopic composition of tree-ring cellulose overcomes restrictions often associated to the analyses of tree-ring width, like inherent biological trends, and the required number of trees to create a robust tree-ring chronology [17-19]. The $\delta^{18} \mathrm{O}$ variations in tree-ring cellulose contain climate signals originating from (i) the isotopic composition of meteoric water (liquid and solid precipitation) used by trees during water uptake by the roots, and (ii) evaporative isotopic enrichment in leaf water which is controlled by various climatic factors controlling tree growth (precipitation, temperature, relative humidity, and sunshine duration) [20-23].

Tree-ring based reconstructions of climate variables have been widely employed in assessing inter-annual climate fluctuations on different time scales [24-26]. Despite the prominent role of tree rings in investigating past climate variability, dendroclimatological analyses have been only sparsely applied so far in Iran. Few explorations of the relationship between tree-ring variables and various climate factors have unlocked tree rings' considerable potential for climate studies, particularly for the mountain regions in the northern, northeastern, and western parts of Iran [27-33]. Nevertheless, only a handful of investigations have utilized dendrochronological methods, using tree-ring width variations, for reconstructions of precipitation variations [5,34,35] in the Zagros Mountains, and of temperature in the north of Iran [36]. Juniperus polycarpos is considered as a valuable timber tree species in Iran, with positive effects on biodiversity and soil conservation [37]. This frost and drought tolerant tree species can grow in harsh environments like the semi-arid mountain regions [38,39] and shows a high sensitivity towards changes in the environment and climate [28-30,36].

Stable oxygen isotope ratios in tree rings have been proven in various regions of the world being a suitable proxy for palaeoclimatic research [40-45]. In this context, stable oxygen isotope ratios in tree-rings of juniper trees have been successfully applied for the long-term (multi-centennial to millennial) reconstruction of moisture and hydroclimatic variations in different climatic regions of Asia $[24,29,46-48]$. In a first evaluation, Foroozan et al. [29] found that precipitation and temperature exert a significant influence on $\delta^{18} \mathrm{O}$ variations in juniper tree rings in north Iran and proved their suitability to reconstruct hydroclimate variations during the early growing season. They indicated that relative humidity or vapor pressure deficit are the best parameters to represent moisture variations driving regional tree-ring $\delta^{18} \mathrm{O}$ variations. Given previous investigations, the $\delta^{18} \mathrm{O}$ variations in juniper 
tree-rings have proven to be significantly more sensitive to precipitation fluctuations than its tree-ring width variations $[29,36,49]$.

In the present study, we established a 501-year spanning tree-ring $\delta^{18} \mathrm{O}$ chronology, representing the first stable isotope archive with the annual resolution for past hydroclimatic investigations in Iran. Our main objectives are to reconstruct (i) regional precipitation and (ii) to study long-term hydroclimatic trends in this climatically sensitive and hardly studied semi-arid region.

\section{Materials and Methods}

\subsection{Study Area}

The Alborz Mountains form a west-east extending barrier between the southern coastline of the Caspian Sea and the inner central Iranian plateau. The mountain range inclines sharply from the Caspian Sea at $26 \mathrm{~m}$ below sea level up to Mount Damavand, the highest mountain in Iran of $5671 \mathrm{~m}$ a.s.l. [50]. It hence serves as a climatological barrier for humid air masses flowing from the Caspian Sea southwards to the Interior parts of Iran [3], causing steep climate gradient and related vegetation changes between the northern and southern slopes of the Alborz Mountains. Consequently, the annual rainfall ranges from $2000 \mathrm{~mm}$ on the north-facing side of the Alborz Mountains to about $25 \mathrm{~mm}$ in the interior parts of the Iranian Plateau. On average, the estimated amount of precipitation across Iran reaches only $250 \mathrm{~mm}[51,52]$. Consequently, the northern slopes of the Alborz Mountains are characterized by the lush vegetation of the Hyrcanian forest, whereas the southern slopes are dominated by leeside and foehn effects resulting in a more arid climate. Accordingly, the dominant vegetation on the southern slopes belongs to the steppic Irano-Turanian vegetation zone [38].

The study site is situated in the eastern part of the Alborz mountain forests, in the Irano-Turanian vegetation zone. The regional woodlands are dominated by open stands of Juniperus polycarpos C. Koch (1700-2500 $\mathrm{m}$ a.s.l.) growing on shallow and calcareous soils [39,53] with $\mathrm{pH}$ values ranging from 7.7 to 8.7 , indicating weakly alkaline soils [54]. Due to steep slopes resulting in well-drained soils, trees have only sporadic or no access to groundwater.

The regional, typically continental climate is characterized by long and cold winters followed by a dry, hot summer with slight cloud cover and therefore intensive solar radiation. Instrumental meteorological stations with available climate data for more than 50 years are mostly located far and in a considerable vertical distance from the study site in the mountain forelands or in valley bottoms (Figure 1). Very few high elevation stations in the surroundings of study areas have recorded climate data albeit for very short periods, almost 20 years, whilst there are also many missing data in these records.

In the absence of climate stations at higher altitudes of the Alborz Mountains, the closest and highest available meteorological station is Mojen station ( $36^{\circ} 29^{\prime} \mathrm{N} ; 54^{\circ} 37^{\prime} \mathrm{E} ; 1970 \mathrm{~m}$ a.s.l.), which is located $21 \mathrm{~km}$ east of our study site at the southern slope of the Alborz Mountains and shows comparable ecological characteristics. Mojen station has an average annual precipitation of approximately $256 \mathrm{~mm}$ and a mean annual temperature of $10^{\circ} \mathrm{C}$ for the measuring period 1982-2019. The highest and lowest monthly mean temperatures occur in July $\left(21.62^{\circ} \mathrm{C}\right)$ and January $\left(-1.57^{\circ} \mathrm{C}\right)$, respectively. The wet season starts from late autumn and continues to winter until June $(11 \mathrm{~mm})$. Precipitation occurs very irregularly, with the highest amounts of precipitation originating from westerly airflows during the winter season from January $(24.9 \mathrm{~mm})$ to March $(43.8 \mathrm{~mm})$ and early spring. The mean duration of winter snow cover is 104 days. In contrast, lowest precipitation amounts occur in August $(7.8 \mathrm{~mm})$ during the dry and warm summer season (July-September). 


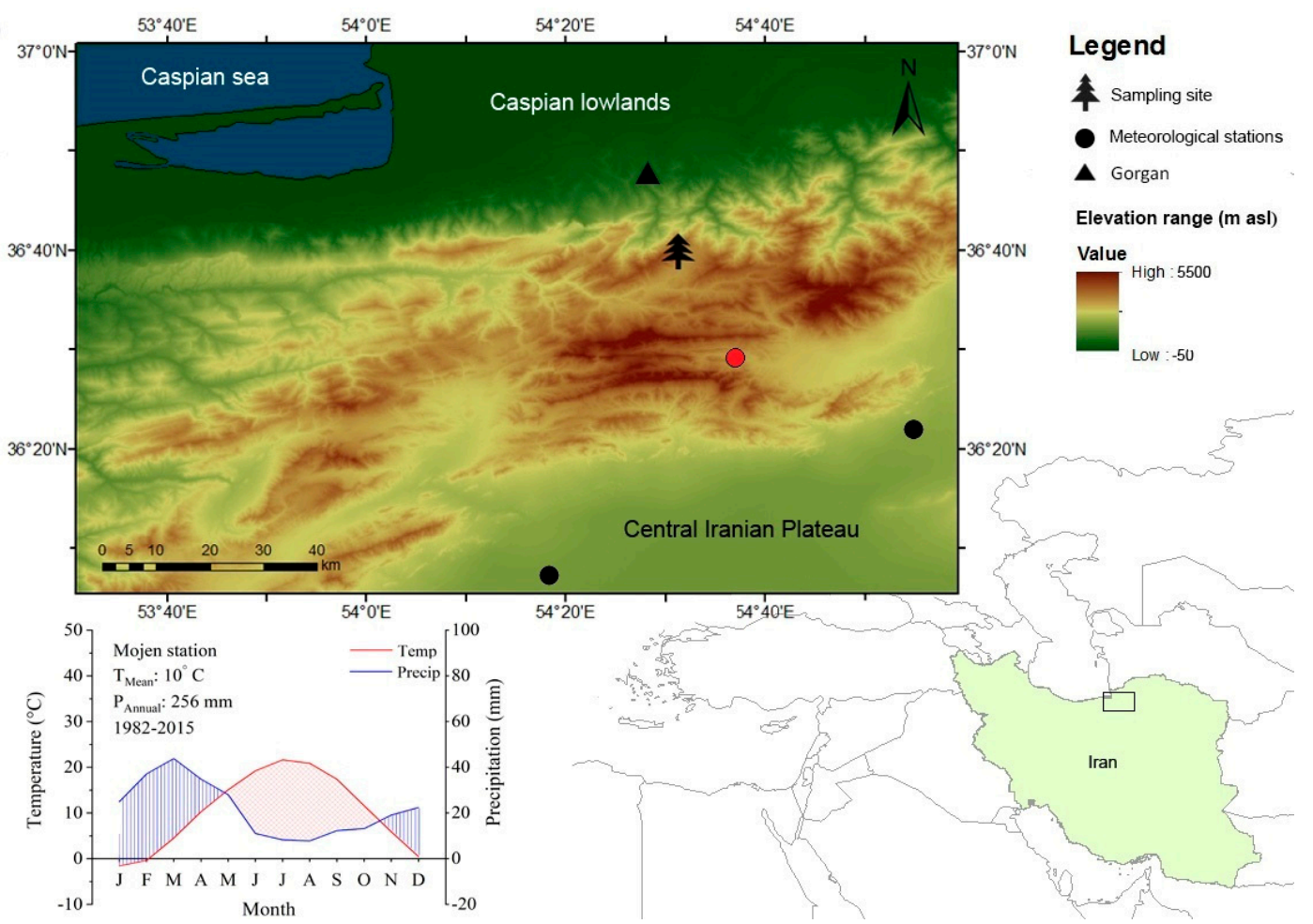

Figure 1. Location of Iran and the study area (rectangle in overview map). Tree symbol: sampling site, Triangle: Gorgan provincial capital, Circle: meteorological stations, Mojen meteorological station marked with red circle. Inlay: climate diagram of Mojen meteorological station (1982-2015).

\subsection{Sample Collection and Preparation}

Samples were collected from an open J. polycarpos forest ( $36^{\circ} 39^{\prime} 54.4^{\prime \prime} \mathrm{N} ; 54^{\circ} 31^{\prime} 53.7^{\prime \prime}$ E) at an elevation of $2540 \mathrm{~m}$ a.s.l. near the village of Chahar Bagh in the southwestern highlands of Golestan province. In order to develop a multi-century stable oxygen chronology, long-living juniper trees were cored at breast height using a $5 \mathrm{~mm}$ increment borer. For the late period, additional samples were acquired by collecting disks of old building timbers in the village Chahar Bagh. After air-drying the increment cores, surfaces of the samples were carefully sanded and prepared to make tree-width boundaries clearly visible [55]. Following standard dendrochronological methods, tree ring widths were first measured with a Lintab 5 table (Rinntech, Heidelberg, Germany) at a resolution of $0.01 \mathrm{~mm}$ and then were statistically and visually cross dated to the exact calendar year against already available regional tree-ring chronologies using the TSAP-Win software package [56].

In accordance with recommendations from previous studies [57,58], a sample replication of at least five trees was ensured over the entire period of investigation (Figure 2). The average single series length is 248 years, with the longest individual having 487 years. The oldest five samples are available since $1515 \mathrm{AD}$, resulting in a full chronology time spanning from AD 1515 to 2015. Subsequently, a standard protocol was followed for cutting tree rings precisely under a binocular and split into smaller pieces using a razor blade [57].

\subsection{Development of the Stable Oxygen Isotope Chronology}

Since the extremely narrow tree rings of junipers pose an analytical challenge to provide sufficient material for isotope analyses, equal wood masses of five individuals of exactly dated trees (1957-1515) were pooled prior to isotopic analysis and further processed for $\alpha$-cellulose extraction. In previous methodological studies evaluating the common signal between individual isotope series from juniper trees [29] and the suitability of different pooling methods, we demonstrated that this number of trees and the approach of inter-tree pooling is the best alternative to individual-tree isotope measurements [59]. 
Inter-tree pooling enables the establishment of a reliable regional $\delta^{18} \mathrm{O}$ isotope chronology providing a representative climate signal for the region. To calculate chronology quality parameters like expressed population signal (EPS) and inter-tree correlation [60] for our $\delta^{18} \mathrm{O}$ chronology, stable oxygen isotopes ratios of the last 58 years (1958-2015), were analyzed individually for the included trees (Figure 2). Since inter-tree pooling results in only one single annual $\delta^{18} \mathrm{O}$ value for each year, calculation of Rbar and EPS was not possible for the chronology sequence 1515-1958.

We extracted $\alpha$-cellulose of bulk wood material following the chemical multi-stage procedure described by [61]. The $\alpha$-cellulose samples were subsequently homogenized using an ultrasonic system, freeze-dried, and loaded into silver capsules. The stable oxygen isotope compositions of $\alpha$-cellulose samples were measured by an isotope ratio mass spectrometer (Delta V Advantage, Thermo Fisher) interfaced to a high temperature $\left(1450{ }^{\circ} \mathrm{C}\right)$ pyrolysis reactor (HT Oxygen Analyzer). The analytical precision of $\delta^{18} \mathrm{O}$ measurement was typically better than $\pm 0.25 \%$.

\subsection{Climate Reconstruction and Statistical Analysis}

To determine the proxy-precipitation relationships, we calculated Pearson's correlation coefficients between tree-ring $\delta^{18} \mathrm{O}$ and precipitation data obtained from several instrumental and modeled sources available for the study site. We also tested correlations with vapor pressure and temperature data from CRU TS $4.03,0.5^{\circ} \times 0.5^{\circ}$ grids [62], and Mojen climate station, respectively.

According to the high correlation coefficients between $\delta^{18} \mathrm{O}$ and precipitation records from the nearby meteorological station of Mojen, this station was selected for further in-depth calibration analyses at monthly and seasonal time scales. The calibration of the oxygen isotope series with precipitation data was accomplished by calculating Pearson's correlation coefficients over the time span from January of the previous year (py J) until September of the current year (S). Furthermore, the total precipitation of different seasons: previous January-March (py winter; py JFM), April-June (py spring; py AMJ), current January-March (winter; JFM), and April-June (spring; AMJ) seasons were calculated and correlated with the $\delta^{18} \mathrm{O}$ series. Based on the highest observed correlations between the $\delta^{18} \mathrm{O}$ chronology and seasonalized precipitation data during the calibration period of 1982-2015, a linear regression model was developed to reconstruct past precipitation conditions.

Due to the short period of available instrumental records (34 years; 1982-2015), the leave-one-out cross-validation method was employed to assess the reliability and stability of the transfer function trough time [63]. Thus, reconstruction evaluation parameters including the reduction of error (RE), the sign test (ST), F-test, Durbin-Watson test and product means test (PMT) were calculated [15] using the open source R software [64].

In order to identify dry/wet events, we defined the intensity of dry/wet years following the classification introduced by Liu et al. [65]: dry year $<$ mean $-1 \sigma$, wet year $>$ mean $+1 \sigma$, extreme dry year $<$ mean $-2 \sigma$, extreme wet year $>$ mean $+2 \sigma$. We additionally conducted Wavelet analyses to identify significant periodicities of precipitation variations in our multi-century reconstructed data. In doing so, the 'morlet wavelet analysis' [66] method was employed using the dplR package in the open software R [67].

In order to further validate the reconstruction with regional historical datasets, we collected information on historical hydrological extreme events recorded throughout Persian history and compared them with our reconstructed precipitation series [68-72]. We also compared our reconstruction with two other existing precipitation reconstructions established for western Iran to analyze the coherence of precipitation fluctuations on decadal time scales and to test for the spatial extent of extreme events at annual resolution. The available reconstructions have been derived from tree-ring width data of oak (Quercus macranthera) from the central and southern Zagros Mountains, respectively $[5,34]$. Therefore, we calculated Pearson correlations and moving correlations between the respective paleoclimate reconstructions.

To test for the influence of large-scale atmospheric circulation patterns on our local spring precipitation reconstruction, we also computed correlations between our reconstructed precipitation 
and several climatic indices, including the North Atlantic Oscillation (NAO) and the Atlantic Multi-decadal Oscillation (AMO), which were downloaded from the National Oceanic and Atmospheric Administration (NOAA) databank (www.esrl.noaa.gov).

\section{Results and Discussion}

\subsection{Characteristics of the Tree-Ring $\delta^{18} O$ Chronology}

Our resulting $\delta^{18} \mathrm{O}$ chronology extends from 2015 back to $1515 \mathrm{AD}$ (Figure 2). The mean $\delta^{18} \mathrm{O}$ value of the chronology is $30.94 \%$ o \pm 0.91 , with a range of $\delta^{18} \mathrm{O}$ values between $28.51 \%$ o and $33.64 \%$, respectively (Table 1). The average Rbar and EPS calculated for the period 1958-2015 were 0.48 $(p<0.01)$ and 0.92 . This exceeds the commonly accepted threshold of 0.85 for sufficient signal strength of a chronology [60], indicating a high consistency between individual trees' isotope series. Hence, we are confident that isotope chronology is also robust for the time before 1958, for which isotope samples were pooled for individual years (Figure 2).

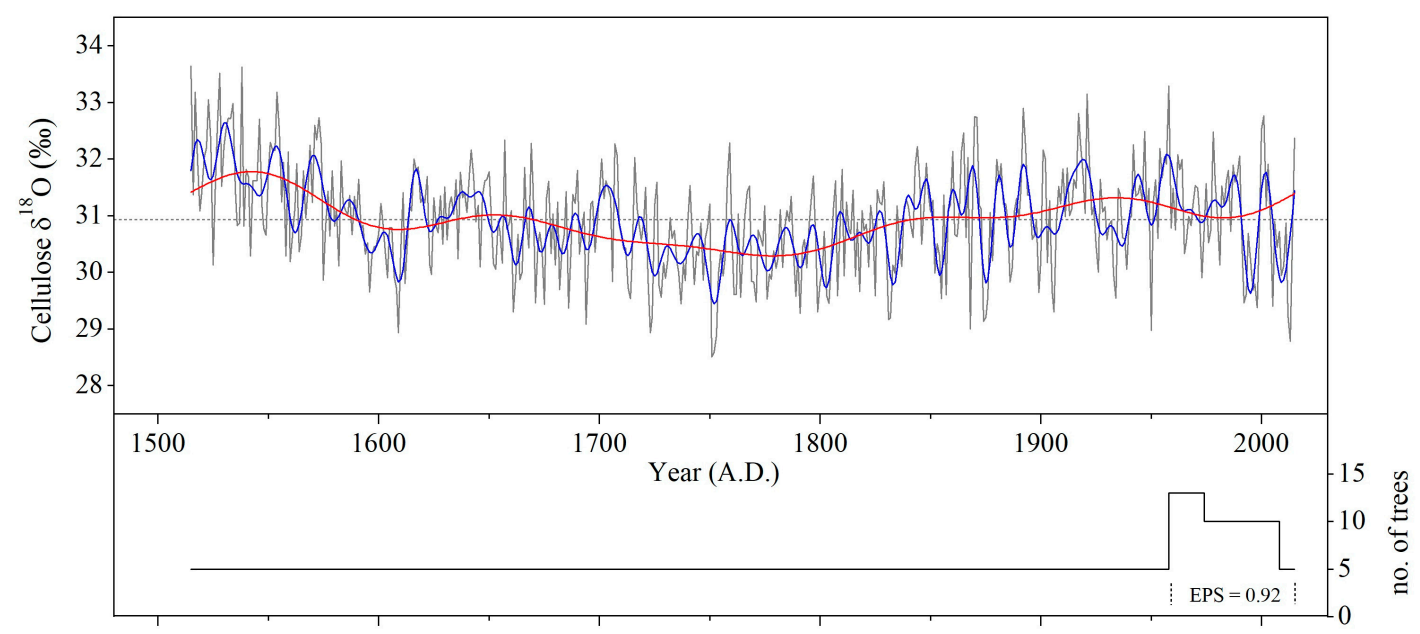

Figure 2. Tree-ring stable oxygen isotope chronology of Juniperus polycarpos from the southern slope of the Alborz Mountains over the period 1515-2015. Blue and red lines represent decadal and centennial $\delta^{18} \mathrm{O}$ variations calculated with 10 and 100 Fast Fourier transform (FFT)-Filters, respectively. The overall mean value of the tree-ring $\delta^{18} \mathrm{O}$ chronology (horizontal black dotted line) and the number of trees included in the chronology are presented in the lower panel.

Table 1. Chronology statistics of the $\delta^{18} \mathrm{O}$ time series of J. polycarpos in northern Iran.

\begin{tabular}{cc}
\hline Statistical Parameters & 1515-2015 \\
\hline Mean (\%o) & 30.94 \\
Minimum (\%o) & 28.51 \\
Maximum (\%o) & 33.64 \\
Range (\%o) & 5.13 \\
Std. deviation & 0.91 \\
Variance & 0.82 \\
Standard error of mean (\%o) & 0.04 \\
AC1 & 0.41 \\
Skewness & 0.08 \\
Kurtosis & -0.02 \\
\hline
\end{tabular}

The first-order autocorrelation coefficient (AC1) was 0.41 , indicating a significant influence of the previous year on the isotopic composition of the current tree ring. Trees with the access to snow meltwater or/and groundwater stored over one growing season can carry the climate signal of the preceding year along with the actual climate signal [73-75]. Moreover, memory effects stemming from 
the incorporation of carbohydrates taken up during preceding years into the earlywood cell walls formed in the following year may contribute to the isotope signal of the whole tree ring. Considering the often very narrow tree rings of junipers of ca. $0.1 \mathrm{~mm}$ and their small portions of latewood, we nevertheless had to conduct stable isotope analyses for whole tree rings.

Our multi-century $\delta^{18} \mathrm{O}$ chronology showed higher oxygen isotope values during the 16th century. Since the mid-16th century, a steady decline in tree ring $\delta^{18} \mathrm{O}$ values can be observed (Figure 2). From ca. $1670-1840, \delta^{18} \mathrm{O}$ values stayed below the 501 -year mean $\delta^{18} \mathrm{O}$ values for two centuries, with a gradual increase since $1790 \mathrm{AD}$. With regard to findings of Foroozan et al. [29], more humid local climate conditions can be inferred for this period, as it was identified as a cooler period by Bayramzadeh et al. [36]. After $1850 \mathrm{AD}$, the stable oxygen isotope ratios are constantly above the long-term mean, indicating generally drier climate conditions in northern Iran.

\subsection{Climate- $\delta^{18} O$ Response}

Figure 3 illustrates the proxy-climate relationships as derived from calibration analyses between our $\delta^{18} \mathrm{O}$ series and climate data from Mojen station.

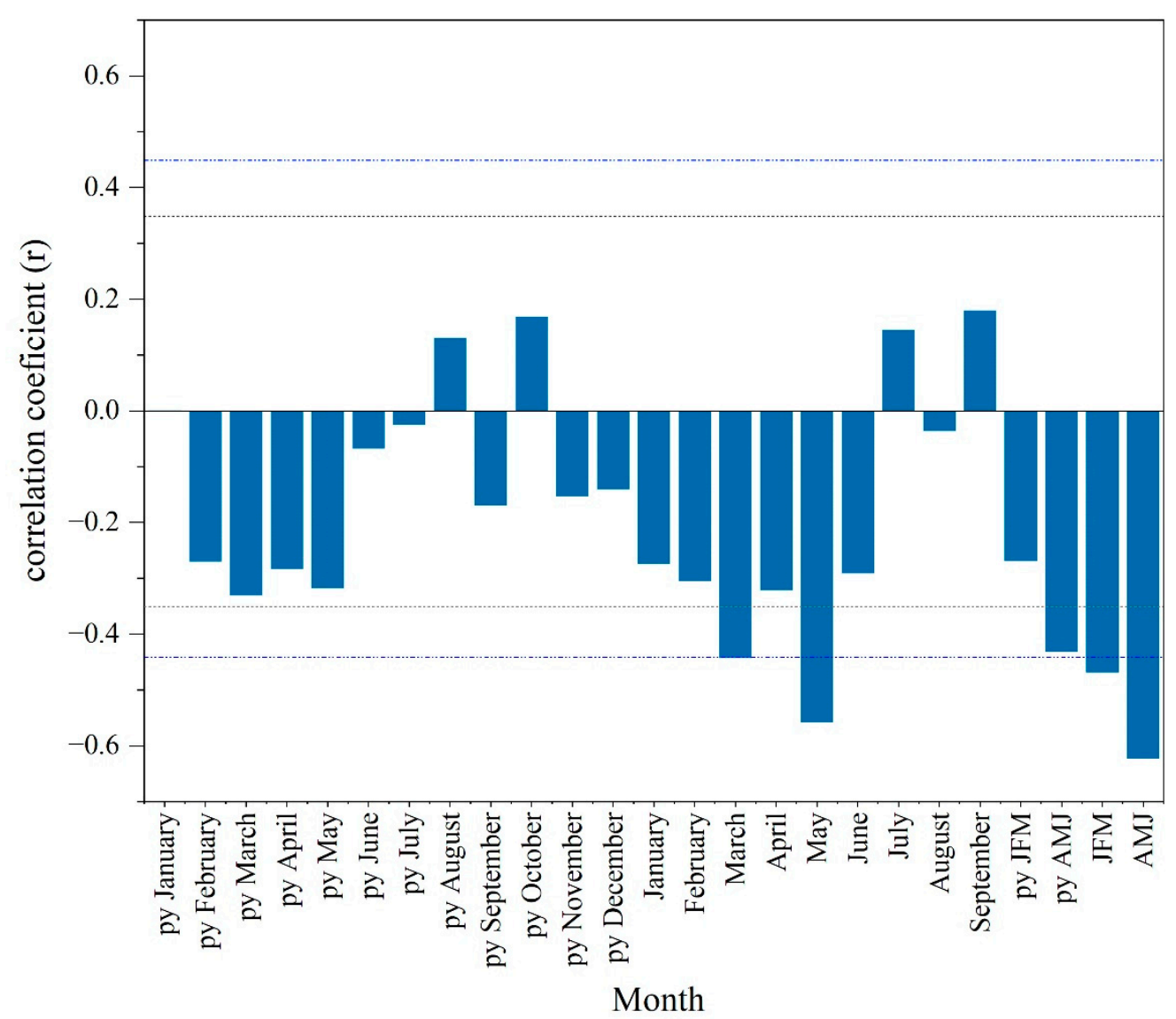

Figure 3. Correlations between tree-ring $\delta^{18} \mathrm{O}$ and monthly and seasonal precipitation during the period 1982-2015. Correlations were calculated for a 21-month period from January of the previous year (py January) until September of the current year, and seasonally averaged data of the previous (January. February. March, as previous winter: py JFM; April. May. June, as previous spring: py AMJ) and current (January. February. March, as winter: JFM; April. May. June, as spring: AMJ) years. Gray and blue horizontal lines indicate significance levels at $p<0.05$ and $p<0.01$, respectively.

In general, a significant negative relationship was observed between tree-ring $\delta^{18} \mathrm{O}$ values with monthly precipitation during spring and winter months in both the current and previous year. Like in other studies conducted in Asia, statistically significant negative correlations were found between the 
tree-ring $\delta^{18} \mathrm{O}$ values and precipitation $[24,45,47,76-78]$. Strongest negative correlations are apparent for tree-ring $\delta^{18} \mathrm{O}$ and April-June seasonal precipitation during the year of growth $(\mathrm{r}=-0.62, p<0.01)$, indicating the major influence of spring precipitation on tree-ring $\delta^{18} \mathrm{O}$ variations during the calibration period (AD 1982-2015) (Figure 3).

In general, the variability of the oxygen isotope composition of plant organic material, such as tree-ring cellulose, depends on three main sources. The first source of $\delta^{18} \mathrm{O}$ variability is determined by the source water absorbed from the soil by tree roots, which flows through the xylem into the leaf without further fractionation $[79,80]$. Source water for trees derives from meteoric water including local rainfall and snow, and from water stored in deeper soil layers or groundwater. The $\delta^{18} \mathrm{O}$ of source water is determined by the isotopic composition of precipitation, which varies mainly with temperature $[57,81]$. The $\delta^{18} \mathrm{O}$ of precipitation in high latitudes is in positive relation with temperature during droplet formation, so that winter precipitation under cold conditions will be more depleted in $\delta^{18} \mathrm{O}[20,81-83]$. Further, $\delta^{18} \mathrm{O}$ in soil water alters by residence time in the soil and evaporation from the upper soil layers, causing the highest $\delta^{18} \mathrm{O}$ enrichment in the superficial water pool [84]. However, trees growing under drought conditions may use the deeper soil water pool, if the superficial soil moisture is depleted. Accordingly, such trees can show a different source water signal from the enriched $\delta^{18} \mathrm{O}$ signal of the upper soil layers [85-87].

The second source of tree-ring $\delta^{18} \mathrm{O}$ variability is the $\delta^{18} \mathrm{O}$ variations in leaf water. Within leaves, the $\delta^{18} \mathrm{O}$ signal of the source water is modified at the evaporative sites as the result of evaporative losses of the lighter water isotopologues $\mathrm{H}^{16} \mathrm{O}$ during transpiration $[88,89]$. This indicates the key role of relative humidity determining the gradient of the water vapor pressure in the intercellular air spaces and the air around the leaves on transpiration rate, and consequently on the evaporative enrichment of leaf water $[23,88,90,91]$. Accordingly, plants growing at higher vapor pressure deficit are expected to have higher leaf water enrichment [92]. However, this is the case when the variation in evaporative demand controls the transpiration rate [89]. The other likely scenario happens when the dominant advection of non $-\delta^{18} \mathrm{O}$ enriched water from the xylem to the evaporative sites hinders the isotopically enriched water to diffuse back from the evaporative sites to the leaf lamina, where it mixes with unenriched xylem water, which is called Péclet-effect $[88,89,93]$. According to the conceptual Péclet model, the greater the Péclet number, the less the enrichment of water in the leaf will be. However, conifer needles have a rather low density of stomata, and their transportation rates are relatively low. In addition, the variation of their effective path length for water movement through the mesophyll is not very well understood [94]. In this concept, some studies even applied a two-pool model as a sufficient alternative to explain the leaf water enrichment in conifers [94,95]. The two-pool model proposes the existence of two separate water pools within leaves, the unenriched source water mainly in the major veins and the enriched water in the evaporative site, to explain the difference between the isotopic enrichment of leaf water and evaporative site. Either way, compared with the positive effect of the evaporation on leaf water enrichment, the negative effect of the Péclet model is negligible and will further diminish through the process of tree-ring formation. Hence it does not have a considerable effect on isotopic signals in tree-ring cellulose [23,96].

The ${ }^{18} \mathrm{O}$ signature of leaf water enrichment will be imprinted on sucrose during assimilation, by which oxygen atoms exchange between enriched leaf water and carbonyl groups. Sucrose is then carried down along the trunk through the phloem to the cambium cells, where additional oxygen atom exchange occurs between sucrose and source (xylem) water during cellulose biosynthesis [97]. Based on initial measurements, an enrichment factor of $27 \%$ on average is considered for $\delta^{18} \mathrm{O}$ of cellulose relative to $\delta^{18} \mathrm{O}$ of the source water [98-100]. Thus, the isotopic signal of cellulose will eventually reflect the $\delta^{18} \mathrm{O}$ signal of the source water and leaf water enrichment, relative to their relative strength.

Due to the shallow root system of junipers, trees in this study use the superficial soil water pools during the growing season, which probably contain a mixture of solid winter precipitation (snow) and liquid precipitation falling during the early growing season. Therefore, the significant negative correlation $(\mathrm{r}=-0.47, p<0.05)$ between the tree-ring $\delta^{18} \mathrm{O}$ and winter (January-March) precipitation 
during the current year points to a probable use of less ${ }^{18} \mathrm{O}$ enriched water by the trees coming from snowmelt during the early growing season for earlywood formation (Figure 3 ).

With regard to the negative effects of vapor pressure during spring on $\delta^{18} \mathrm{O}$ values $(\mathrm{r}=-0.58$, $p<0.01)$ in junipers, the strong negative correlation between spring precipitation and cellulose $\delta^{18} \mathrm{O}$ can be explained by the influence of precipitation on vapor pressure and plant transpiration. Accordingly, a growing season with higher precipitation results in lower vapor pressure deficit and plant transpiration, and consequently to a lower enrichment of leaf water $\delta^{18} \mathrm{O}$. Lower evaporative enrichment on the leaf level will lead to carbohydrates with a lower $\delta^{18} \mathrm{O}$ signature, which will be transported via the phloem down the stem to be finally incorporated in wood cellulose $[23,101]$.

The significant positive $\delta^{18} \mathrm{O}$-temperature relationship $(\mathrm{r}=0.49, p<0.01)$ supports our interpretation that the $\delta^{18} \mathrm{O}$ signal in tree-ring cellulose rather reflects variations in leaf water evaporative enrichment than in source water. Actually, the temperature has an indirect effect on $\delta^{18} \mathrm{O}$ variations in juniper tree-rings by increasing evaporative enrichment during spring.

Regarding the highest negative $\delta^{18} \mathrm{O}$-precipitation correlation, the total sum of spring precipitation of the current and the previous year $(\mathrm{r}=-0.72, p<0.01)$ was chosen as the most robust predictor of $\delta^{18} \mathrm{O}$ variations in tree rings in our study site (Table 2).

Table 2. Correlation coefficient $(r)$ and explained variance $\left(R^{2}\right)$ between the Chahar Bagh Juniper $\delta^{18} O$ chronology and precipitation.

\begin{tabular}{ccccc}
\hline & py AMJ + AMJ & MAM & JFMAMJ & py AM + AM \\
\hline $\mathbf{r}$ & -0.72 & -0.64 & -0.63 & -0.71 \\
$\mathbf{R}^{2}$ & 0.52 & 0.41 & 0.40 & 0.50 \\
\hline \multicolumn{5}{c}{ All correlations are significant at the 0.01 level. }
\end{tabular}

\subsection{Precipitation Reconstruction}

We developed the following linear regression model to reconstruct the variations in the combined total precipitation of py AMJ + AMJ in northern Iran back to 1515 AD:

$$
\mathrm{Y}=-36.10 \times \delta^{18} \mathrm{O}+1257.44
$$

Verification statistics for our precipitation reconstruction including the reduction of error (RE), the sign test (ST), F-stat, Durbin-Watson test, and product means test (PMT) $[15,102,103]$ are shown in Table 3. The resulting reconstruction explained $52 \%$ of the actual precipitation py AMJ + AMJ variance during the calibration period. The Durbin-Watson (DW) statistic was less than 2 (DW =1.14), meaning that moderate autocorrelation is apparent in the regression residuals of the calibration model (Table 3). Positive RE and an F-test value of 33.90 confirmed the validity and reliability of the linear regression model (Table 3). According to the significant sign-test, the number of agreements and disagreements between the reconstructed and instrumental data [15], indicates consistency in the high-frequency variations of the actual and reconstructed values (Table 3). In summary, the statistical results proved the stability and predictive skill of the regression model.

Table 3. Statistics of the leave-one-out cross-validation method for the precipitation py AMJ + AMJ reconstruction using linear regression. $\mathrm{R}^{2}$ : Explained variance, $\mathrm{R}^{2}$ adj: Adjusted explained variance, $\mathrm{F}$ : F-stat, RE: Reduction of Error, ST: Sign test, DW: Durbin-Watson test, PMT: Product means test.

\begin{tabular}{cccccccc}
\hline Period & $\mathbf{R}^{\mathbf{2}}$ & $\mathbf{R}^{\mathbf{2}}{ }_{\text {adj }}$ & $\mathbf{F}$ & $\mathbf{R E}$ & $\mathbf{S T}$ & $\mathbf{D W}$ & PMT \\
\hline $1983-2015$ & 0.52 & 0.50 & 33.90 & 0.45 & $21^{+} / 12^{-}$ & 1.14 & 4.19 \\
\hline
\end{tabular}

Based on these verification results, we reconstructed precipitation during the early growing season (py AMJ + AMJ) using Equation (1) for the 501-year long period from 1515 to 2015 (Figure 4). 
Unfortunately, the shortness of the climate data series covering only 34 years does not allow for testing the stationarity of the climate-proxy relationships. However, the explanations of the tree-ring isotope relations are meaningful from a tree physiological point of view, since the reconstructed climatic window covers the main growing season of the trees. Therefore, we have confidence that the detected main climate influence on the isotope variation in the studied trees was also valid in other climate periods and that the presented reconstruction is trustworthy.

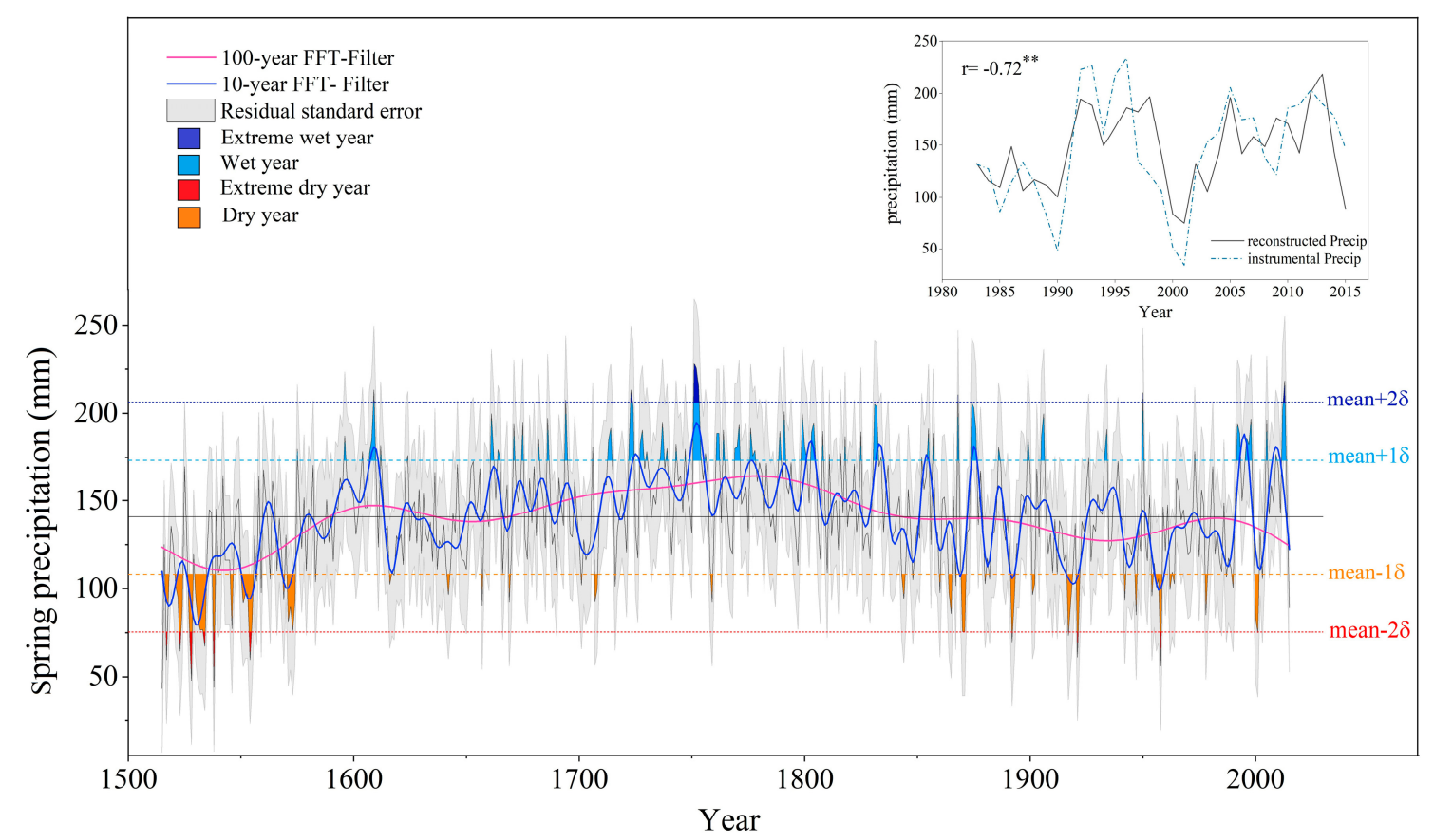

Figure 4. Reconstruction of spring precipitation py AMJ + AMJ for the southern slope of the Alborz Mountains during the period 1515-2015. Blue and red lines represent decadal and centennial $\delta^{18} \mathrm{O}$ variations calculated with 10 and 100-year FFT-Filters, respectively. The horizontal black and dotted colored lines indicate the 501-year mean and dry/wet and extreme dry/wet events, respectively, based on the dryness/wetness classification by Liu et al. [65]. Inlay rectangle: comparison between the reconstructed and instrumental precipitation variations during the calibration period of 1983-2015.

The mean total precipitation py AMJ + AMJ reconstructed for 1515-2015 was $140.7 \pm 32.7 \mathrm{~mm}$. On a centennial timescale, the 16th century showed the highest negative deviation below the 501-year average precipitation (mean precip $=120 \mathrm{~mm}$ ) (Figure 4 ). However, this period showed a gradual tendency towards wetter conditions into the 17th century. From ca. 1665-1840, spring precipitation stayed above average (Figure 4). The most humid periods occurred during the second half of the 18th century. These humid periods seem to coincide with cold periods at the beginning of the 17 th and 18th century and 1749 until 1830, as reported by Bayramzadeh et al. [36]. In contrast, the 19th and 20th centuries witnessed a gradual decline in spring precipitation (Figure 4). Our finding is consistent with results by Khaleghi [32], who postulated for northeastern Iran a long-term declining precipitation trend over the last two centuries.

Years with relatively dry/wet AMJ periods were identified as dry year $<108 \mathrm{~mm}$, wet year $>173.4 \mathrm{~mm}$, extreme dry year $<75.4 \mathrm{~mm}$, and extreme wet year $>206 \mathrm{~mm}$, respectively. The identification of dry/wet events revealed that our multi-century reconstruction consists of $68 \%$ normal years, 17\% years with relatively wet and extremely wet AMJ periods, and 15\% years with relatively dry and extremely dry AMJ periods (Tables A1 and A2). About 38\% of wet and extreme wet events of the last 501 years were observed during the 18th century (Figure 4, Table 4). Hence, the 18th century was the wettest century during the past 501 years, with a mean total precipitation of $157.7 \mathrm{~mm}$. The highest frequencies of dry and extremely dry year events occurred in the 16th century, the driest 
period of the past 501 years (Figure 4, Table 4). The 20th century can be characterized as the driest century since the past 400 years (mean precip $=133.3 \mathrm{~mm}$ ), with the highest frequencies of the dry and extreme dry events since the 16th century. Throughout the last three centuries, the occurrence of dry events continued to rise, whereas wet year events decreased. However, the frequency of the occurrence of extreme events increased in this period (Table 4). In accordance with the NDWMC report, years with dry and wet conditions have frequently occurred in Iran during the last 30 years, while the frequency of dry years is higher [104].

Table 4. Frequency of occurrence of dry/wet and extreme dry/wet events.

\begin{tabular}{cccccccc}
\hline & \multicolumn{6}{c}{ Century (No. of Years Observed) } \\
\cline { 2 - 7 } Dry/Wet Year Classification & 16th & 17th & 18th & 19th & 20th & $\begin{array}{c}\text { 21st } \\
\text { (2000-2015) }\end{array}$ \\
\hline Dry & 30 & 6 & 5 & 12 & 17 & 4 \\
Wet & 2 & 15 & 31 & 21 & 12 & 4 \\
Extremely dry & 7 & - & - & 1 & 3 & 1 \\
Extremely wet & - & 2 & 4 & 1 & 1 & 1 \\
\hline
\end{tabular}

Based on our precipitation reconstruction, the duration of the dry periods varied from one year to maximum five years, whilst one and two year dry periods occurred more frequently, as $70 \%$ and $21 \%$ of dry periods lasted for one and two years, respectively. The highest frequencies of one and two year length dry period has been reported for the southern Zagros Mountains in Southwest Iran [5,34] (Table A1). Longer dry periods of $4-5$ years, that account for $9 \%$ of the dry periods, arose only in the 16th century. The periods 1530-1534, 1551-1555, and 1956-1958 were the longest periods with drier conditions during the 16th and 20th centuries (Table A1). The persistence of wet periods varies from one to three years, whilst $64 \%$ of wet periods lasted for one year and $21 \%$ and $13 \%$ lasted for two and three years, respectively. However, one wet period in the 18th century (1751-1754) lasted for four years. Prolonged wet periods occurred mostly in the 18th century and included about $57 \%$ of three year wet periods of the last five centuries (Table A1).

Figure 5 compares the annual and decadal scale fluctuations in the reconstructed total spring precipitation py AMJ + AMJ for the period 1840-2015, for which other precipitation reconstructions from neighboring regions are available. In particular, our reconstructed precipitation py AMJ + AMJ synchronized with reconstructed dry events in 1860-1861 [105,106], 1870-1871, 1917-1919, 1942-1945 [34], and 1958 [5,107]. Additionally, dry years in our reconstruction were contemporaneous to negative pointer years in western Asia in 1917 and 1961 [27]. Hydrological extreme events have been recurring throughout Persian history. Although Iran covers a vast area, several historic meteorological disasters resulting from widespread flood and drought occurred throughout the country. Three catastrophic famines that occurred during 1869-1873, 1917-1919, and 1942-1944 have been reported by historical documents [68-72]. In compliance with historical records, the decadal-frequency observations of reconstructed spring precipitation (py AMJ + AMJ) indicate that the decline in precipitation since 1861 lead to the severe drought and famine in 1870-1872 that affected almost the whole country, while eastern and northeastern Iran were affected in 1870-1871 [69,70,72] (Figure 5a). The great drought disasters of 1917-1919 and 1942-1944 were also observed in our study region [71,108] (Figure 5a).

Likewise, historical documents recorded widespread and serious flooding in 1867, 1885, 1924-1925, the 1930s, and 1948-1949 (1950, northeastern-Mashhad) distinguished by heavy and continuous rainfalls in different months [68]. Unprecedented, torrential rainfalls have been frequently reported by observations during the 1930s around our study site, for instance in April 1931, May 1933, April 1934 (northeastern, Mashhad), and 1939 (March in Mashhad, whole spring in Birjand). In agreement with historical documents, our reconstruction registered the years 1868, 1886, 1926, 1933-1934, and 1950 as wet years at the southern slopes of the Alborz Mountains. Besides, the decadal mean precipitation stayed above the overall mean during the 1930s. 
As recorded by the nearest meteorological stations Shahroud, Semnan, Mashhad, Bojnord and Sabzevar, the region experienced two common noteworthy decadal scale periods of low spring precipitation since 1950. In agreement with the nearby climate stations records, our reconstruction reveals a significant decrease in precipitation in the 1980s [32]. This reduction is followed by a considerable increase starting in the middle of the 1990s. Afterwards, the famous severe drought during the last years of the 20th century from 1999 to 2001 occurred (Figure 5a). The severe 1999-2001 drought is one of the largest persistent droughts globally since the 1940s, affecting Central and Southwest Asia, with the most severe impact on Iran, Afghanistan, Tajikistan, Western Pakistan, Uzbekistan, and Turkmenistan [1,109]. This drought affected more than 20 provinces of Iran, whereby the area around our study site was among the most affected ones.

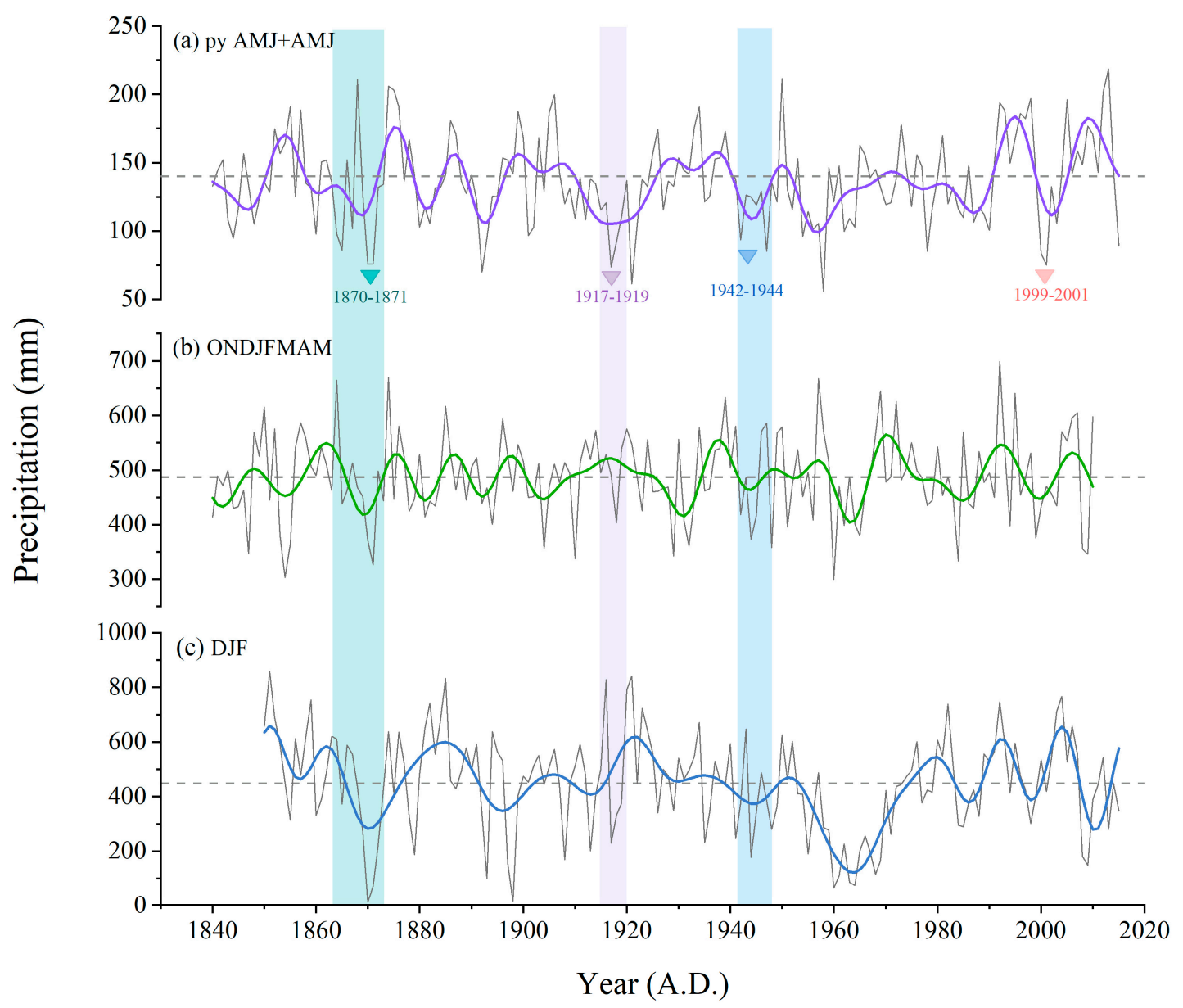

Figure 5. Comparison between the annual and decadal (bold lines) variations of the reconstructed spring precipitation py AMJ + AMJ and two precipitation reconstructions from the Zagros Mountains, west Iran. (a) Reconstructed precipitation py AMJ + AMJ in the present study, (b) October to May precipitation in the central Zagros Mountains during 1840-2010 [34], (c) December to February precipitation in the southern Zagros Mountains during 1850-2015 [5]. Colored bars indicate historical famine and drought periods.

We also compared our precipitation reconstruction with two other tree-ring-width based reconstructions of December-February [5] and October-May precipitation [34] from the Zagros Mountains in western Iran (Figure 5). The October-May reconstructed precipitation by Azizi et al. [34] (Figure $5 b)$ was significantly $(r=0.20, p<0.05)$ correlated with our spring precipitation reconstruction over the common period of 1840-2010. In addition, a significant correlation between our reconstruction and December-February precipitation for the southern Zagros Mountain by Arsalani et al. [5] (Figure 5c) 
was observed for 1850-2015 $(\mathrm{r}=0.16, p<0.05)$. As both reconstructions are located quite far from our study site in northern Iran, the correlation coefficients are expectably low.

Nonetheless, moving correlations reveal that significant correlations between reconstructed spring precipitation in the Alborz Mountains and precipitation variations in the Zagros Mountains are restricted to the second half of the 19th century $\left(\mathrm{P}_{\mathrm{O}-\mathrm{M}}=1855-1918\right)$ and the 20th century $\left(\mathrm{P}_{\mathrm{O}-\mathrm{M}}=\right.$ 1972-2008 and $\mathrm{P}_{\mathrm{D}-\mathrm{F}}=1922-1964$ ) (Figure 6). Since precipitation variations in the Zagros Mountains are mainly controlled by the mid-latitude westerlies, bringing moisture from the North Atlantic Ocean and the Mediterranean Sea, these correlations point to a temporally strong influence of westerly winds on spring precipitation in the eastern Alborz Mountains. However, we found no significant correlation between our reconstruction and large-scale climatic indices representing the westerlies' influence/strength (NAO, AMO).

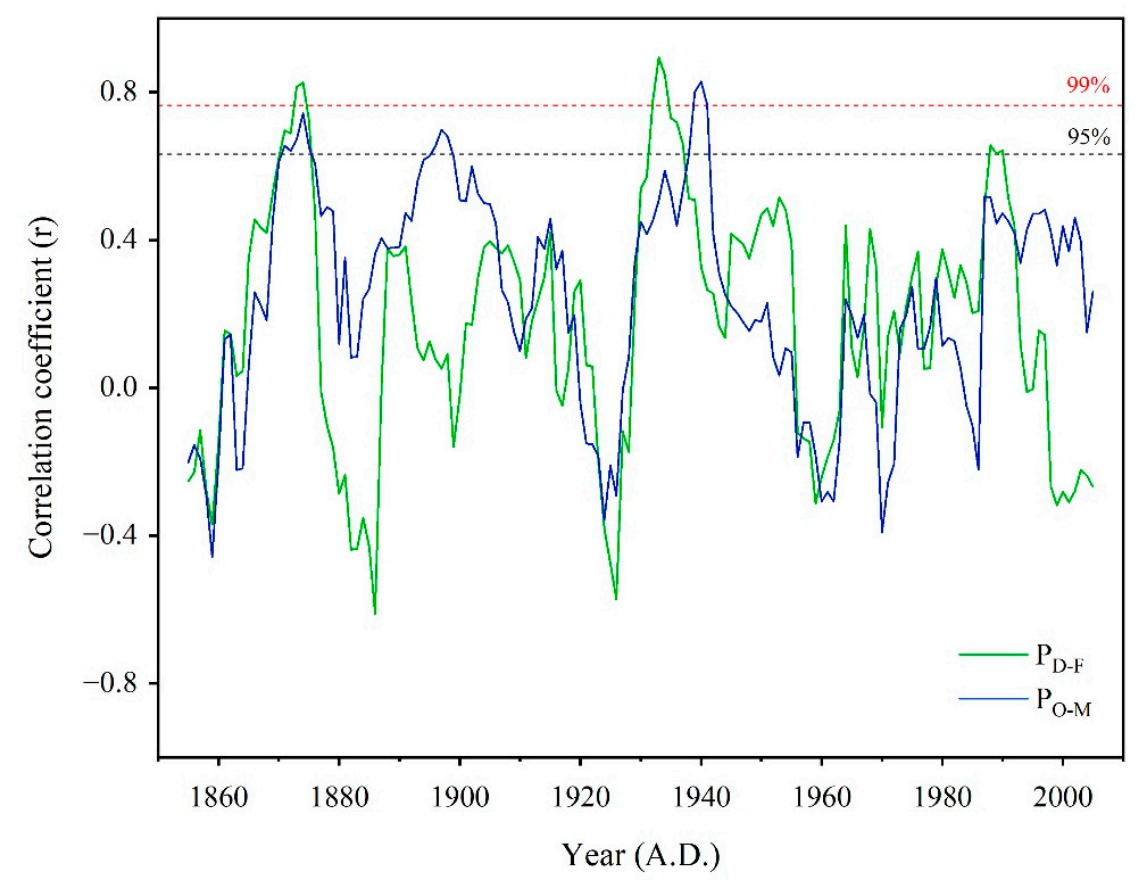

Figure 6. The 30-year moving correlation coefficients between our spring precipitation reconstruction in the Alborz Mountain, northeast Iran, and two precipitation reconstructions from the Zagros Mountains, west Iran, during 1850-2010. $\mathrm{P}_{\mathrm{D}-\mathrm{F}}$ and $\mathrm{P}_{\mathrm{O}-\mathrm{M}}$ represent December to February precipitation in the southern Zagros Mountains during 1850-2015 [5] and October to May precipitation at the central Zagros Mountains during 1840-2010 [34], respectively. Black and red horizontal lines indicate the 95\% and $99 \%$ confidence limits, respectively.

A wavelet analysis revealed that the presence of significant periodicities in our reconstructed precipitation is not persistent over the study period (Figure 7). Significant cycles of precipitation fluctuations with periodicities lower than ca. 15 years appear during the 16th and at the beginning of 17 centuries, and during the late 19th and 20th centuries. These observations point to a variable strength of the influence of the westerlies on precipitation variations at our study side and a strong influence of regional atmospheric factors. These factors include the influence of local topography, the high elevation of our study site, and the regional climatic effect of the nearby Caspian Sea, for which no long-term data are yet available. 


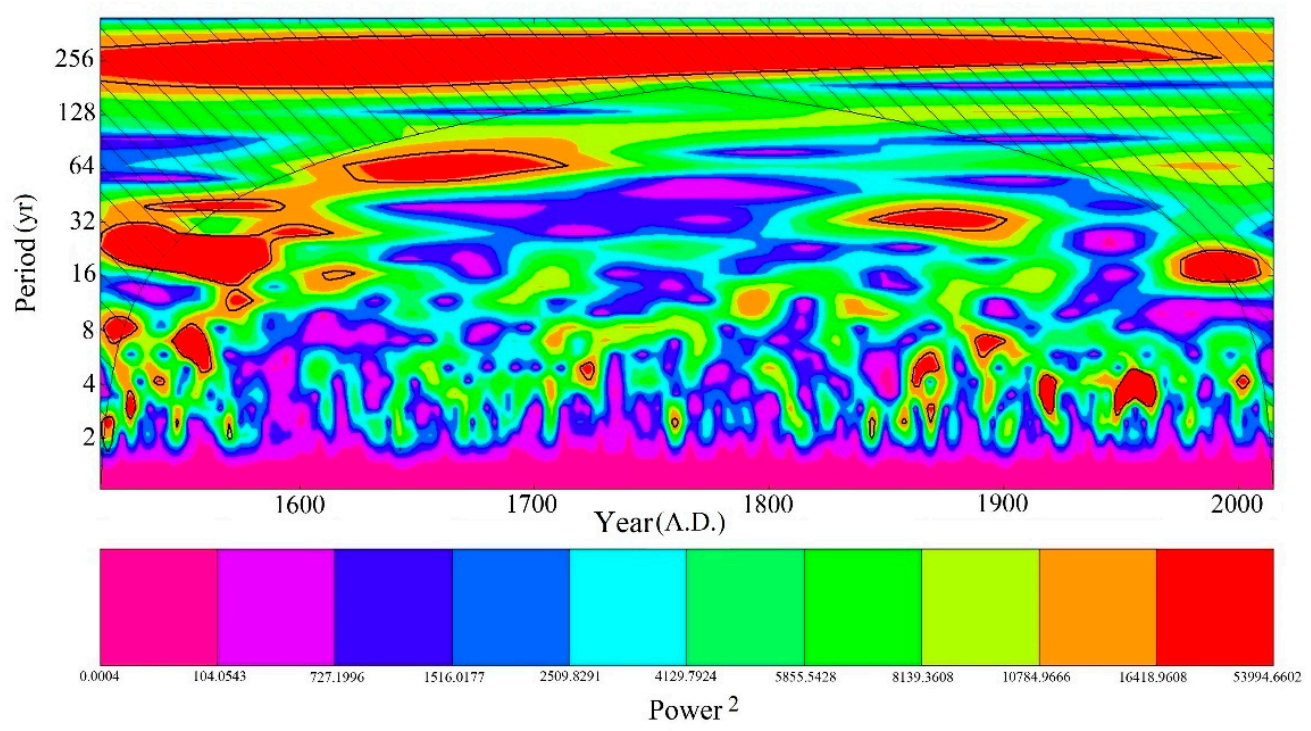

Figure 7. Wavelet analysis of the spring precipitation reconstruction py AMJ + AMJ from 1515 to 2015. Detected periodicities highlighted by black outline are significant at the $95 \%$ confidence level.

\section{Conclusions}

We developed a multi-century tree-ring stable oxygen isotope chronology from J. polycarpos and developed the first multi-centennial spring precipitation reconstruction for the semi-arid region of northern Iran. Despite the short instrumental climate record, the verification statistics confirmed the validity and reliability of the linear regression model. Our reconstruction reveals the 18th (the 16th) century as the wettest (driest) period during the last 501 years. Our findings indicate a gradual decline in spring precipitation from the beginning of the 19th century until the ongoing dry period of the 20th century.

Our precipitation reconstruction additionally manifest variations and extreme events in spring rainfall and the occurrence of extreme climate events increased over the last 501 years. Periods of common climate signals between our reconstruction and two other tree-ring width-based precipitation reconstructions for western Iran indicated some common forcing factors.

The present study has taken an important step in improving our knowledge of hydroclimatic variations in the semi-arid northern Iran, which is of great relevance for sustainable water management. Given the deficiency of other hydroclimate proxies in the region, a denser network of annually resolved proxy series is still needed for a better understanding of spatio-temporal variability of climate and effects of global climate change on the ecosystems in semi-arid regions in northern Iran.

Author Contributions: Conceptualization, A.B., K.P., and J.G.; methodology, writing and original draft preparation, all authors; formal analysis and visualization, Z.F.; validation, Z.F., J.G., A.B.; resources, A.B.; supervision, A.B., K.P., J.G. All authors have read and agreed to the published version of the manuscript.

Funding: This research received no external funding.

Acknowledgments: We gratefully acknowledge Christoph Mayr and Roswitha Höfner-Stich for laboratory analyses. The authors would like to thank Mohsen Arsalani who graciously provided us with the reconstructed precipitation series from the Zagros Mountains for comparison. We are particularly grateful to Iris Burchardt for helpful comments and technical assistance during sample preparation, and to Sugam Aryal for invaluable advice on statistical analyses. We express our deep appreciation to the German Academic Exchange Service (DAAD) and Bavarian Equal Opportunities Sponsorship_Realisierung von Frauen in Forschung und Lehre (FFL) -Promotion Equal Opportunities for Women in Research and Teaching, for the financial support of Z.F.

Conflicts of Interest: The authors declare no conflict of interest. 


\section{Appendix A}

Table A1. Reconstructed dry and wet periods for the southern slope of the Alborz Mountains during the period 1515-2015.

\begin{tabular}{|c|c|c|c|}
\hline Dry Periods & No. of Years & Wet Periods & No. of Years \\
\hline 1515 & 1 & 1575 & 1 \\
\hline 1517-1518 & 2 & 1596 & 1 \\
\hline $1521-1524$ & 4 & 1604 & 1 \\
\hline $1527-28$ & 2 & $1607-1609$ & 3 \\
\hline 1530-1534 & 5 & 1612 & 1 \\
\hline 1538 & 1 & 1624 & 1 \\
\hline 1546 & 1 & $1661-1662$ & 2 \\
\hline $1551-1555$ & 5 & 1664-1665 & 2 \\
\hline 1557 & 1 & 1671 & 1 \\
\hline 1559 & 1 & 1675 & 1 \\
\hline 1563 & 1 & 1682 & 1 \\
\hline 1569 & 1 & 1686 & 1 \\
\hline $1571-1574$ & 4 & 1694 & 1 \\
\hline 1583 & 1 & 1706 & 1 \\
\hline 1616 & 1 & $1713-1714$ & 2 \\
\hline 1618 & 1 & $1722-1724$ & 3 \\
\hline 1642 & 1 & $1727-1728$ & 2 \\
\hline 1657 & 1 & 1730 & 1 \\
\hline 1666 & 1 & $1736-1737$ & 2 \\
\hline 1669 & 1 & 1739 & 1 \\
\hline 1701 & 1 & 1743 & 1 \\
\hline 1707-1708 & 2 & 1747 & 1 \\
\hline 1716 & 1 & $1751-1754$ & 4 \\
\hline 1759 & 1 & 1756 & 1 \\
\hline 1844 & 1 & $1761-1762$ & 2 \\
\hline 1848 & 1 & 1764 & 1 \\
\hline 1860 & 1 & 1769-1771 & 3 \\
\hline 1864-1865 & 2 & $1776-1778$ & 3 \\
\hline 1867 & 1 & 1789 & 1 \\
\hline 1870-1871 & 2 & 1791 & 1 \\
\hline 1880 & 1 & 1799-1801 & 3 \\
\hline 1882 & 1 & 1803-1804 & 2 \\
\hline $1892-1893$ & 2 & 1808 & 1 \\
\hline 1901-1902 & 2 & 1811 & 1 \\
\hline 1917-1918 & 2 & 1816 & 1 \\
\hline 1921-1922 & 2 & 1818 & 1 \\
\hline 1942 & 1 & 1825 & 1 \\
\hline 1947 & 1 & $1831-1832$ & 2 \\
\hline 1954 & 1 & 1834 & 1 \\
\hline 1956-1958 & 3 & 1852 & 1 \\
\hline 1962 & 1 & 1855 & 1 \\
\hline 1964 & 1 & 1857 & 1 \\
\hline 1978 & 1 & 1868 & 1 \\
\hline 1987 & 1 & 1874-1876 & 3 \\
\hline 1990 & 1 & 1886 & 1 \\
\hline 2000-2001 & 2 & 1899 & 1 \\
\hline 2003 & 1 & 1905-1906 & 2 \\
\hline \multirow[t]{9}{*}{2015} & 1 & 1926 & 1 \\
\hline & & 1933-1934 & 2 \\
\hline & & 1950 & 1 \\
\hline & & 1973 & 1 \\
\hline & & 1992-1993 & 2 \\
\hline & & 1996-1998 & 3 \\
\hline & & 2005 & 1 \\
\hline & & 2009 & 1 \\
\hline & & 2012-2013 & 2 \\
\hline
\end{tabular}


Table A2. Reconstructed extreme-dry and -wet events for the southern slope of the Alborz Mountains during the period 1515-2015.

\begin{tabular}{cc}
\hline Extreme Dry Events & Extreme Wet Events \\
\hline 1515 & 1609 \\
1517 & 1694 \\
1523 & 1723 \\
1528 & 1751 \\
1534 & 1752 \\
1538 & 1753 \\
1554 & 1868 \\
1892 & 1950 \\
1917 & 2013 \\
1921 & \\
1958 & \\
2001 & \\
\hline
\end{tabular}

\section{References}

1. Barlow, M.; Zaitchik, B.; Paz, S.; Black, E.; Evans, J.; Hoell, A. A review of drought in the Middle East and southwest Asia. J. Clim. 2016, 29, 8547-8574. [CrossRef]

2. Veldkamp, T.I.E.; Wada, Y.; Aerts, J.C.J.H.; Ward, P.J. Towards a global water scarcity risk assessment framework: Incorporation of probability distributions and hydro-climatic variability. Environ. Res. Lett. 2016, 11. [CrossRef]

3. Modarres, R.; Sarhadi, A. Statistically-based regionalization of rainfall climates of Iran. Glob. Planet. Chang. 2011, 75, 67-75. [CrossRef]

4. Madani, K. Water management in Iran: What is causing the looming crisis? J. Environ. Stud. Sci. 2014, 4, 315-328. [CrossRef]

5. Arsalani, M.; Pourtahmasi, K.; Azizi, G.; Bräuning, A.; Mohammadi, H. Tree-ring based December-February precipitation reconstruction in the southern Zagros Mountains, Iran. Dendrochronologia 2018, 49, 45-56. [CrossRef]

6. Tabari, H.; Willems, P. More prolonged droughts by the end of the century in the Middle East. Environ. Res. Lett. 2018, 13, 104005. [CrossRef]

7. Evans, J.P. 21st century climate change in the Middle East. Clim. Chang. 2009, 92, 417-432. [CrossRef]

8. UNFCCC. Climate Change: Impacts, Vulnerabilities and Adaptation in Developing Countries; United Nations Framework Convention on Climate Change; UNFCCC Secretariat: Bonn, Germany, 2007.

9. IPCC. Summary for Policymakers. In Global Warming of $1.5^{\circ} \mathrm{C}$; Masson-Delmotte, V., Zhai, P., Pörtner, H.-O., Roberts, D., Skea, J., Shukla, P.R., Pirani, A., Moufouma-Okia, W., Péan, C., Pidcock, R., et al., Eds.; An IPCC Special Report on the impacts of global warming of $1.5^{\circ} \mathrm{C}$ above pre-industrial levels and related global greenhouse gas emission pathways, in the context of strengthening the global response to the threat of climate change, sustainable development, and efforts to eradicate poverty; 2018; in press.

10. Rahimi, J.; Malekian, A.; Khalili, A. Climate change impacts in Iran: Assessing our current knowledge. Theor. Appl. Climatol. 2019, 135, 545-564. [CrossRef]

11. Shifteh Some'e, B.; Ezani, A.; Tabari, H. Spatiotemporal trends and change point of precipitation in Iran. Atmos. Res. 2012, 113, 1-12. [CrossRef]

12. Soltani, S.; Saboohi, R.; Yaghmaei, L. Rainfall and rainy days trend in Iran. Clim. Chang. 2012, 110, $187-213$. [CrossRef]

13. Abbaspour, K.C.; Faramarzi, M.; Ghasemi, S.S.; Yang, H. Assessing the impact of climate change on water resources in Iran. Water Resour. Res. 2009, 45, 413. [CrossRef]

14. Tabari, H.; Aghajanloo, M.-B. Temporal pattern of aridity index in Iran with considering precipitation and evapotranspiration trends. Int. J. Climatol. 2013, 33, 396-409. [CrossRef]

15. Fritts, H. Tree Rings and Climate; Elsevier Science: Oxford, UK, 1976; ISBN 9780122684500.

16. Hughes, M.K. Dendrochronology in climatology-The state of the art. Dendrochronologia 2002, 20, 95-116. [CrossRef] 
17. Helle, G.; Schleser, G.H. Interpreting Climate Proxies from Tree-rings. In The Climate in Historical Times: Towards a Synthesis of Holocene Proxy Data and Climate Models; Fischer, H., Ed.; Springer: Berlin/Heidelberg, Germany, 2011; pp. 129-148. ISBN 978-3-642-05826-4.

18. Young, G.H.F.; Demmler, J.C.; Gunnarson, B.E.; Kirchhefer, A.J.; Loader, N.J.; McCarroll, D. Age trends in tree ring growth and isotopic archives: A case study of Pinus sylvestris L. from northwestern Norway. Glob. Biogeochem. Cycles 2011, 25. [CrossRef]

19. Loader, N.J.; Young, G.H.F.; McCarroll, D.; Wilson, R.J.S. Quantifying uncertainty in isotope dendroclimatology. Holocene 2013, 23, 1221-1226. [CrossRef]

20. Dansgaard, W. Stable isotopes in precipitation. Tellus 1964, 16, 436-468. [CrossRef]

21. Roden, J.S.; Lin, G.; Ehleringer, J.R. A mechanistic model for interpretation of hydrogen and oxygen isotope ratios in tree-ring cellulose. Geochim. Cosmochim. Acta 2000, 64, 21-35. [CrossRef]

22. Barbour, M.M. Stable oxygen isotope composition of plant tissue: A review. Funct. Plant Biol. 2007, $34,83$. [CrossRef]

23. Gessler, A.; Ferrio, J.P.; Hommel, R.; Treydte, K.; Werner, R.A.; Monson, R.K. Stable isotopes in tree rings: Towards a mechanistic understanding of isotope fractionation and mixing processes from the leaves to the wood. Tree Physiol. 2014, 34, 796-818. [CrossRef]

24. Grießinger, J.; Bräuning, A.; Helle, G.; Hochreuther, P.; Schleser, G. Late Holocene relative humidity history on the southeastern Tibetan plateau inferred from a tree-ring $\delta^{18} \mathrm{O}$ record: Recent decrease and conditions during the last 1500 years. Quat. Int. 2017, 430, 52-59. [CrossRef]

25. Huang, R.; Zhu, H.; Liang, E.; Asad, F.; Grießinger, J. A tree-ring-based summer (June-July) minimum temperature reconstruction for the western Kunlun Mountains since AD 1681. Theor. Appl. Climatol. 2019, 48, 3381. [CrossRef]

26. Opała-Owczarek, M. Warm-season temperature reconstruction from high-elevation juniper tree rings over the past millennium in the Pamir region. Palaeogeogr. Palaeoclimatol. Palaeoecol. 2019, 532, 109248. [CrossRef]

27. Pourtahmasi, K.; Parsapajouh, D.; Bräuning, A.; Esper, J.; Schweingruber, F.H. Climatic analysis of pointer years in tree-ring chronologies from Northern Iran and neighboring high mountain areas. Geokodynamik 2007, 28, 27-42.

28. Pourtahmasi, K.; Bräuning, A.; Poursartip, L.; Burchardt, I. Growth-climate responses of oak and juniper trees in different exposures of the Alborz Mountains, northern Iran. Trace 2012, 10, 49-53.

29. Foroozan, Z.; Pourtahmasi, K.; Bräuning, A. Stable oxygen isotopes in juniper and oak tree rings from northern Iran as indicators for site-specific and season-specific moisture variations. Dendrochronologia 2015, 36, 33-39. [CrossRef]

30. Foroozan, Z.; Pourtahmasi, K.; Bräuning, A. Climatic signals in stable carbon isotope ratios of Juniper and Oak tree rings from northern Iran. Glob. Planet. Chang. 2018, 165, 90-99. [CrossRef]

31. Gholami, V.; Ahmadi Jolandan, M.; Torkaman, J. Evaluation of climate change in northern Iran during the last four centuries by using dendroclimatology. Nat. Hazards 2017, 85, 1835-1850. [CrossRef]

32. Khaleghi, M.R. Application of dendroclimatology in evaluation of climatic changes. J. For. Sci. 2018, 64, 139-147. [CrossRef]

33. Arsalani, M.; Bräuning, A.; Pourtahmasi, K.; Azizi, G.; Mohammadi, H. Multiple tree-ring parameters of Quercus brantii Lindel in SW Iran show a strong potential for intra-annual climate reconstruction. Trees 2018, 32, 1531-1546. [CrossRef]

34. Azizi, G.; Arsalani, M.; Bräuning, A.; Moghimi, E. Precipitation variations in the central Zagros Mountains (Iran) since A.D. 1840 based on oak tree rings. Palaeogeogr. Palaeoclimatol. Palaeoecol. 2013, 386, 96-103. [CrossRef]

35. Arsalani, M.; Azizi, G.; Bräuning, A. Dendroclimatic reconstruction of May-June maximum temperatures in the central Zagros Mountains, western Iran. Int. J. Climatol. 2015, 35, 408-416. [CrossRef]

36. Bayramzadeh, V.; Zhu, H.; Lu, X.; Attarod, P.; Zhang, H.; Li, X.; Asad, F.; Liang, E. Temperature variability in northern Iran during the past 700 years. Sci. Bull. 2018, 63, 462-464. [CrossRef]

37. Fallah, A.; Balapour, S.A.; Yekekhani, M.; Jalilvand, H. Dendrochronological studies of Juniperus polycarpos in alborz mountains: (Case study: Shahkuh of shahrood). Iran. J. Wood Paper Sci. Res. 2014, 29, 94-105.

38. Sagheb-Talebi, K.; Sajedi, T.; Pourhashemi, M. Forests of Iran. A Treasure from the Past, a Hope for the Future; Springer: Dordrecht, The Netherlands, 2014; ISBN 9400773714. 
39. Fatemi, S.S.; Rahimi, M.; Tarkesh, M.; Ravanbakhsh, H. Predicting the impacts of climate change on the distribution of Juniperus excelsa M. Bieb. In the central and eastern Alborz Mountains, Iran. iForest 2018, 11, 643-650. [CrossRef]

40. Li, Q.; Liu, Y.; Nakatsuka, T.; Zhang, Q.-B.; Ohnishi, K.; Sakai, A.; Kobayashi, O.; Pan, Y.; Song, H.; Liu, R.; et al. Oxygen stable isotopes of a network of shrubs and trees as high-resolution plaeoclimatic proxies in Northwestern China. Agric. For. Meteorol. 2020, 285-286, 107929. [CrossRef]

41. Leonelli, G.; Battipaglia, G.; Cherubini, P.; Saurer, M.; Siegwolf, R.T.W.; Maugeri, M.; Stenni, B.; Fusco, S.; Maggi, V.; Pelfini, M. Larix decidua $\delta^{18} \mathrm{O}$ tree-ring cellulose mainly reflects the isotopic signature of winter snow in a high-altitude glacial valley of the European Alps. Sci. Total Environ. 2017, 579, 230-237. [CrossRef]

42. Lorrey, A.M.; Brookman, T.H.; Evans, M.N.; Fauchereau, N.C.; Macinnis-Ng, C.; Barbour, M.M.; Criscitiello, A.; Eischeid, G.; Fowler, A.M.; Horton, T.W.; et al. Stable oxygen isotope signatures of early season wood in New Zealand kauri (Agathis australis) tree rings: Prospects for palaeoclimate reconstruction. Dendrochronologia 2016, 40, 50-63. [CrossRef]

43. Olson, E.J.; Dodd, J.P.; Rivera, M.A. Prosopis sp. tree-ring oxygen and carbon isotope record of regional-scale hydroclimate variability during the last 9500 years in the Atacama Desert. Palaeogeogr. Palaeoclimatol. Palaeoecol. 2020, 538. [CrossRef]

44. Grießinger, J.; Langhamer, L.; Schneider, C.; Saß, B.-L.; Steger, D.; Skvarca, P.; Braun, M.H.; Meier, W.J.-H.; Srur, A.M.; Hochreuther, P. Imprints of Climate Signals in a 204 Year $\delta^{18} \mathrm{O}$ Tree-Ring Record of Nothofagus pumilio From Perito Moreno Glacier, Southern Patagonia (50 S). Front. Earth Sci. 2018, 6, 564. [CrossRef]

45. Cai, Q.; Liu, Y.; Duan, B.; Li, Q.; Sun, C.; Wang, L. Tree-ring $\delta^{18} \mathrm{O}$, a tool to crack the paleo-hydroclimatic code in subtropical China. Quat. Int. 2018, 487, 3-11. [CrossRef]

46. Wernicke, J.; Grießinger, J.; Hochreuther, P.; Bräuning, A. Variability of summer humidity during the past 800 years on the eastern Tibetan Plateau inferred from $\delta^{18} \mathrm{O}$ of tree-ring cellulose. Clim. Past 2015, 11, 327-337. [CrossRef]

47. Wernicke, J.; Hochreuther, P.; Grießinger, J.; Zhu, H.; Wang, L.; Bräuning, A. Multi-century humidity reconstructions from the southeastern Tibetan Plateau inferred from tree-ring $\delta^{18} \mathrm{O}$. Glob. Planet. Chang. 2017, 149, 26-35. [CrossRef]

48. Wang, H.; Shao, X.; Li, M. A 2917-year tree-ring-based reconstruction of precipitation for the Buerhanbuda Mts., Southeastern Qaidam Basin, China. Dendrochronologia 2019, 55, 80-92. [CrossRef]

49. Pourtahmasi, K.; Poursartip, L.; Bräuning, A.; Parsapajouh, D. Comparison between the radial growth of Juniper (Juniperus polycarpos) and Oak (Quercus macranthera) in two sides of the Alborz Mountains in the Chaharbagh region of Gorgan. Iran J. For. Wood Prod. 2009, 62, 159-169.

50. Noroozi, J.; Körner, C. A bioclimatic characterization of high elevation habitats in the Alborz mountains of Iran. Alp. Bot. 2018, 128, 1-11. [CrossRef]

51. Moameni, A. Production Capacity of Land Resources of Iran; Soil and Water Research Institute: Tehran, Iran, 2000.

52. Mesgaran, M.; Madani, K.; Hashemi, H.; Azadi, P. Evaluation of Land and Precipitation for Agriculture in Iran; Working Paper 2, Stanford Iran 2040 Project; Stanford University: Stanford, CA, USA, 2016; Available online: http://purl.stanford.edu/vf990qz0340 (accessed on 24 June 2020).

53. Ravanbakhsh, H.; HamzeH'Ee, B.; Etemad, V.; Marvie Mohadjer, M.R.; Assadi, M. Phytosociology of Juniperus excelsa M.Bieb. Forests in Alborz mountain range in the north of Iran. Plant Biosyst. Int. J. Deal. Asp. Plant Biol. 2015, 150, 987-1000. [CrossRef]

54. Nezhad, M.M.; Shataee, S.; Habashi, H.; Babanezhad, M. Spatial and statistical analysis of quantitative characteristics of Juniperus stands in Chahar-bagh of Gorgan regarding to topographic and soil features. Iran. J. For. 2013, 5, 195-206.

55. Stokes, M.A.; Smiley, T.L. An Introduction to Tree-Ring Dating; University of Chicago Press: Chicago, IL, USA; London, UK, 1968.

56. Rinn, F. TSAP-WIN. Time Series Analysis and Presentation Dendrochonology and Related Applications; Rinntech: Heidelberg, Germany, 2013.

57. McCarroll, D.; Loader, N.J. Stable isotopes in tree rings. Quat. Sci. Rev. 2004, 23, 771-801. [CrossRef]

58. Leavitt, S.W. Tree-ring C-H-O isotope variability and sampling. Sci. Total Environ. 2010, 408, 5244-5253. [CrossRef] 
59. Foroozan, Z.; Grießinger, J.; Pourtahmasi, K.; Bräuning, A. Evaluation of Different Pooling Methods to Establish a Multi-Century $\delta^{18} \mathrm{O}$ Chronology for Paleoclimate Reconstruction. Geosciences 2019, 9, 270. [CrossRef]

60. Wigley, T.M.L.; Briffa, K.R.; Jones, P.D. On the Average Value of Correlated Time Series, with Applications in Dendroclimatology and Hydrometeorology. J. Clim. Appl. Meteorol. 1984, 23, 201-213. [CrossRef]

61. Wieloch, T.; Helle, G.; Heinrich, I.; Voigt, M.; Schyma, P. A novel device for batch-wise isolation of $\alpha$-cellulose from small-amount wholewood samples. Dendrochronologia 2011, 29, 115-117. [CrossRef]

62. University of East Anglia Climatic Research Unit; Harris, I.C.; Jones, P.D. CRU TS4.03: Climatic Research Unit (CRU) Time-Series (TS) Version 4.03 of High-Resolution Gridded Data of Month-by-Month Variation in Climate (January 1901-December 2018); CEDA: Didcot, UK, 2019.

63. Michaelsen, J. Cross-Validation in Statistical Climate Forecast Models. J. Clim. Appl. Meteorol. 1987, 26, 1589-1600. [CrossRef]

64. R Core Team. R: A Language and Environment for Statistical Computing; R Core Team: Vienna, Austria, 2019; Available online: http://www.R-project.org/ (accessed on 24 June 2020).

65. Liu, Y.; Ta, W.; Li, Q.; Song, H.; Sun, C.; Cai, Q.; Liu, H.; Wang, L.; Hu, S.; Sun, J.; et al. Tree-ring stable carbon isotope-based April-June relative humidity reconstruction since ad 1648 in Mt. Tianmu, China. Clim. Dyn. 2018, 50, 1733-1745. [CrossRef]

66. Torrence, C.; Compo, G.P. A Practical Guide to Wavelet Analysis. Bull. Am. Meteorol. Soc. 1998, 79, 61-78. [CrossRef]

67. Bunn, A.G. A dendrochronology program library in R (dplR). Dendrochronologia 2008, 26, 115-124. [CrossRef]

68. Melville, C. Meteorological Hazards and Disasters in Iran: A Preliminary Survey to 1950. Iran 1984, 22, 113-150. [CrossRef]

69. Okazaki, S. The great Persian famine of 1870-71. Bull. Sch. Orient. Afr. Stud. 1986, 49, 183-192. [CrossRef]

70. Melville, C. The persian famine of 1870-1872: Prices and politics. Disasters 1988, 12, 309-325. [CrossRef]

71. Majd, M.G. The Great Famine E Genocide in Iran. 1917-1919/Mohammad Gholi Majd, 2nd ed.; University Press of America: Lanham, MD, USA, 2013; ISBN 9780761861683.

72. Majd, M.G. A Victorian Holocaust. Iran in the Great Famine of 1869-1873/Mohammad Gholi Majd; Hamilton Books: Lanham, MD, USA, 2017; ISBN 9780761870159.

73. Marshall, J.D.; Monserud, R.A. Co-occurring species differ in tree-ring $\delta^{18} \mathrm{O}$ trends. Tree Physiol. 2006, 26, 1055-1066. [CrossRef]

74. Loader, N.J.; McCarroll, D.; Gagen, M.; Robertson, I.; Jalkanen, R. Extracting Climatic Information from Stable Isotopes in Tree Rings. In Stable Isotopes as Indicators of Ecological Change; Dawson, T.E., Siegwolf, R.T.W., Eds.; Academic: Oxford, UK, 2007; pp. 25-48. ISBN 9780123736277.

75. Saurer, M.; Cherubini, P.; Reynolds-Henne, C.E.; Treydte, K.S.; Anderson, W.T.; Siegwolf, R.T.W. An investigation of the common signal in tree ring stable isotope chronologies at temperate sites. J. Geophys. Res. 2008, 113, 31625. [CrossRef]

76. Liu, X.; Zeng, X.; Leavitt, S.W.; Wang, W.; An, W.; Xu, G.; Sun, W.; Wang, Y.; Qin, D.; Ren, J. A 400-year tree-ring $\delta^{18} \mathrm{O}$ chronology for the southeastern Tibetan Plateau: Implications for inferring variations of the regional hydroclimate. Glob. Planet. Chang. 2013, 104, 23-33. [CrossRef]

77. Qin, C.; Yang, B.; Bräuning, A.; Grießinger, J.; Wernicke, J. Drought signals in tree-ring stable oxygen isotope series of Qilian juniper from the arid northeastern Tibetan Plateau. Glob. Planet. Chang. 2015, 125, 48-59. [CrossRef]

78. Xu, G.; Wu, G.; Liu, X.; Chen, T.; Wang, B.; Hudson, A.; Trouet, V. Age-related climate response of tree-ring $\delta$ $13 \mathrm{C}$ and $\delta^{18} \mathrm{O}$ from spruce in northwestern China, with implications for relative humidity reconstructions. J. Geophys. Res. Biogeosci. 2020. [CrossRef]

79. Ehleringer, J.R.; Dawson, T.E. Water uptake by plants: Perspectives from stable isotope composition. Plant Cell Environ. 1992, 15, 1073-1082. [CrossRef]

80. Ferrio, J.P.; Voltas, J. Carbon and oxygen isotope ratios in wood constituents of Pinus halepensis as indicators of precipitation, temperature and vapour pressure deficit. Tellus B 2005, 57, 164-173. [CrossRef]

81. Rozanski, K.; Araguás-Araguás, L.; Gonfiantini, R. Isotopic Patterns in Modern Global Precipitation. In Climate Change in Continental Isotopic Records; Swart, P.K., Lohmann, K.C., Mckenzie, J., Savin, S., Eds.; American Geophysical Union: Washington, DC, USA, 1993; pp. 1-36. ISBN 9781118664025. 
82. Baldini, L.M.; McDermott, F.; Foley, A.M.; Baldini, J.U.L. Spatial variability in the European winter precipitation $\delta^{18} \mathrm{O}-\mathrm{NAO}$ relationship: Implications for reconstructing NAO-mode climate variability in the Holocene. Geophys. Res. Lett. 2008, 35. [CrossRef]

83. Field, R.D. Observed and modeled controls on precipitation $\delta^{18} \mathrm{O}$ over Europe: From local temperature to the Northern Annular Mode. J. Geophys. Res. 2010, 115. [CrossRef]

84. Wingate, L.; Seibt, U.; Maseyk, K.; Ogée, J.; Almeida, P.; Yakir, D.A.N.; Pereira, J.S.; Mencuccini, M. Evaporation and carbonic anhydrase activity recorded in oxygen isotope signatures of net $\mathrm{CO}_{2}$ fluxes from a Mediterranean soil. Glob. Chang. Biol. 2008, 14, 2178-2193. [CrossRef]

85. Sarris, D.; Siegwolf, R.; Körner, C. Inter- and intra-annual stable carbon and oxygen isotope signals in response to drought in Mediterranean pines. Agric. For. Meteorol. 2013, 168, 59-68. [CrossRef]

86. Saurer, M.; Kirdyanov, A.V.; Prokushkin, A.S.; Rinne, K.T.; Siegwolf, R.T.W. The impact of an inverse climate-isotope relationship in soil water on the oxygen-isotope composition of Larix gmelinii in Siberia. New Phytol. 2016, 209, 955-964. [CrossRef]

87. Szymczak, S.; Barth, J.; Bendix, J.; Huneau, F.; Garel, E.; Häusser, M.; Juhlke, T.; Knerr, I.; Santoni, S.; Trachte, K.; et al. Tracking the oxygen isotope composition from source to sink in pine trees along an elevation gradient in a Mediterranean ecosystem. Chem. Geol. 2020, 549, 119695. [CrossRef]

88. Farquhar, G.D.; Lloyd, J. Carbon and Oxygen Isotope Effects in the Exchange of Carbon Dioxide between Terrestrial Plants and the Atmosphere. In Stables Isotopes and Plant Carbon: Water Relations; Ehleringer, J.R., Hall, A.E., Farquhar, G.D., Eds.; Academic Press: San Diego, CA, USA; Toronto, ON, Canada, 1993; pp. 47-70. ISBN 9780122333804.

89. Farquhar, G.D.; Cernusak, L.A.; Barnes, B. Heavy water fractionation during transpiration. Plant Physiol. 2007, 143, 11-18. [CrossRef]

90. Dongmann, G.; Nürnberg, H.W.; Förstel, H.; Wagener, K. On the enrichment of H2 18-O in the leaves of transpiring plants. Radiat. Environ. Biophys. 1974, 11, 41-52. [CrossRef]

91. Cernusak, L.A.; Barbour, M.M.; Arndt, S.K.; Cheesman, A.W.; English, N.B.; Feild, T.S.; Helliker, B.R.; Holloway-Phillips, M.M.; Holtum, J.A.M.; Kahmen, A.; et al. Stable isotopes in leaf water of terrestrial plants. Plant Cell Environ. 2016, 39, 1087-1102. [CrossRef]

92. Sheshshayee, M.S.; Bindumadhava, H.; Ramesh, R.; Prasad, T.G.; Lakshminarayana, M.R.; Udayakumar, M. Oxygen isotope enrichment (delta18O) as a measure of time-averaged transpiration rate. J. Exp. Bot. 2005, 56, 3033-3039. [CrossRef]

93. Barbour, M.M.; Roden, J.S.; Farquhar, G.D.; Ehleringer, J.R. Expressing leaf water and cellulose oxygen isotope ratios as enrichment above source water reveals evidence of a Péclet effect. Oecologia 2004, 138, 426-435. [CrossRef]

94. Roden, J.; Kahmen, A.; Buchmann, N.; Siegwolf, R. The enigma of effective path length for (18) O enrichment in leaf water of conifers. Plant Cell Environ. 2015, 38, 2551-2565. [CrossRef]

95. Song, X.; Simonin, K.A.; Loucos, K.E.; Barbour, M.M. Modelling non-steady-state isotope enrichment of leaf water in a gas-exchange cuvette environment. Plant Cell Environ. 2015, 38, 2618-2628. [CrossRef]

96. Song, X.; Clark, K.S.; Helliker, B.R. Interpreting species-specific variation in tree-ring oxygen isotope ratios among three temperate forest trees. Plant Cell Environ. 2014, 37, 2169-2182. [CrossRef]

97. Sternberg, L.; Pinzon, M.C.; Anderson, W.T.; Jahren, A.H. Variation in oxygen isotope fractionation during cellulose synthesis: Intramolecular and biosynthetic effects. Plant Cell Environ. 2006, 29, 1881-1889. [CrossRef] [PubMed]

98. DeNiro, M.J.; Epstein, S. Isotopic composition of cellulose from aquatic organisms. Geochim. Cosmochim. Acta 1981, 45, 1885-1894. [CrossRef]

99. Sternberg, L.d.S.; Deniro, M.J.; Savidge, R.A. Oxygen Isotope Exchange between Metabolites and Water during Biochemical Reactions Leading to Cellulose Synthesis. Plant Physiol. 1986, 82, 423-427. [CrossRef] [PubMed]

100. Sternberg, L.S.L. Oxygen and Hydrogen Isotope Ratios in Plant Cellulose: Mechanisms and Applications. In Stable Isotopes in Ecological Research; Rundel, P.W., Ehleringer, J.R., Nagy, K.A., Eds.; Springer: New York, NY, USA, 1989; pp. 124-141. ISBN 978-1-4612-3498-2.

101. Offermann, C.; Ferrio, J.P.; Holst, J.; Grote, R.; Siegwolf, R.; Kayler, Z.; Gessler, A. The long way down-are carbon and oxygen isotope signals in the tree ring uncoupled from canopy physiological processes? Tree Physiol. 2011, 31, 1088-1102. [CrossRef] [PubMed] 
102. Cook, E.R.; Kairiukstis, L.A. Methods of Dendrochronology; Springer: Dordrecht, The Netherlands, 1990; ISBN 978-90-481-4060-2.

103. Cook, E.R.; Briffa, K.R.; Jones, P.D. Spatial regression methods in dendroclimatology: A review and comparison of two techniques. Int. J. Climatol. 1994, 14, 379-402. [CrossRef]

104. NDWMC. Yearbook-2019 of the National Center for Drought and Crisis Management; NDWMC: Tehran, Iran, 2019.

105. Brugsch, H. Reise der K. Preussischen Gesandtschaft Nach Persien, 1860 und 1861, Geschildert; J.C. Hinrichs: Leipzig, Germany, 1862.

106. Kazemi, R. The Black Winter of 1860-61. Comp. Stud. South Asia Afr. Middle East 2017, 37, 24-48. [CrossRef]

107. Touchan, R.; Meko, D.; Hughes, M.K. A 396-year reconstruction of precipitation in southern Jordan. J. Am. Water Resour. Assoc. 1999, 35, 49-59. [CrossRef]

108. Majd, M.G. Iran under Allied Occupation in World War II. The Bridge to Victory E a Land of Famine/Mohammad Gholi Majd; University Press of America: Lanham, MD, USA, 2016; ISBN 9780761867395.

109. Agrawala, S.; Barlow, M.; Cullen, H.; Lyon, B. The drought and humanitarian crisis in central and southwest Asia: A climate perspective. IRI Rep. 2001, 1-11. [CrossRef]

(C) 2020 by the authors. Licensee MDPI, Basel, Switzerland. This article is an open access article distributed under the terms and conditions of the Creative Commons Attribution (CC BY) license (http://creativecommons.org/licenses/by/4.0/). 